\title{
Интемектуамьная природа права в основных концепциях правопонимания
}

\author{
А. А. косых \\ Академия управления МВД России, г. Москва, Российская Федерация \\ ORCID: https://orcid.org/0000-0002-3563-6848, e-mail: lexovip36@mail.ru
}

Ре ферат

Введение: зарождение правовых норм, их трансформация, специализация и отраслевая дифференциация, формирование системы права - все это свидетельствует о постоянном качественном, интеллектуально обоснованном развитии права. В статье проводится анализ основных концепций правопонимания (естественно-правовой, исторической, психологической, нормативистской, марксистской, антропологического подхода) на предмет определения сущности (природы) права. Исследование сущностных основ права выступает главной задачей не только теории права и государства, но и других наук (философии права, социологии права, истории правовых учений). Цель работы состоит в исследовании интеллектуальной природы права на основе анализа трудов представителей различных концепций правопонимания. Методы: выводы и умозаключения автора основываются на использовании материалистической диалектики, сравнительно-правовом, социологическом и историческом методах. Обсуждение: примечательно, что в каждой концепции правопонимания интеллект (ум, разум, рассудок) рассматривается учеными как неотъемлемый элемент процесса правообразования. Выводы: право рассматривается в рамках антропологического подхода как результат интеллектуальной деятельности человека не только по своему происхождению, но и сущностному основанию, своей природе. Выдвигается тезис о том, что право есть результат интеллектуально-разумной мыслительной деятельности человека, предлагается авторская дефиниция права.

К л юч е в ы е с л о в а: право; сущность права; разум; интеллект; концепция правопонимания.

12.00.01 - Теория и история права и государства; история учений о праве и государстве.

Для цитирования: Косых А. А. Интеллектуальная природа права в основных концепциях правопонимания. Пенитенциарная наука, 2021, т. 15, № 4 (56), c. 709-720. DOI 10.46741/2686-9764-2021-15-4-709-720.

\section{Intellectual Nature of Law in the Basic Concepts of Understanding Law}

\author{
ALEKSEI A. KOSYKH \\ Academy of Management of the Ministry of Internal Affairs of the Russian \\ Federation, Moscow, Russian Federation \\ ORCID: https://orcid.org/0000-0002-3563-6848, e-mail: lexovip36@mail.ru
}

Abstract

Introduction: formation of legal norms and their transformation, creation of the legal system, specialization and sectoral differentiation of legal norms indicate constant qualitative, intellectually grounded development of law. In the article the author analyzes basic concepts of understanding law (natural, historical, psychological, normative, 
Marxist, of anthropological approach) in order to determine the essence (nature) of law. The study of essential foundations of law is a fundamental task not only for the theory of law and state, but also for other sciences (philosophy of law, sociology of law, history of legal doctrines). The purpose of the work is to study an intellectual nature of law on the basis of analysis of various concepts of understanding law. Methods: the author's key conclusions and findings are based on the use of materialistic dialectics in comparative legal, sociological and historical methods. Discussions: it is noteworthy that in each concept of understanding law, intelligence (mind, reason, common sense) is considered by scientists as an integral element of the process of legal education. Conclusions: taking into account the stated above, the author proposes to consider law within the framework of an anthropological approach as a result of human intellectual activity not only by its origin, but also by its essential basis, its nature. The author puts forward the thesis that law is the result of intelligence-based thinking activity of a person and suggests the author's definition of law.

K e y w o r d s : law; essence of law; reason; intelligence; concept of understanding law.

12.00.01 - Theory and history of the law and state; history of the law and state studies.

For citation: Kosykh A.A. Intellectual nature of law in the basic concepts of understanding law. Penitentiary Science, 2021, vol. 15, no. 4(56), pp. 709-720. DOI 10.46741/2686-9764-2021-15-4-709-720.

\section{Введение}

В декабре 2020 г. состоялась видеоконференция по вопросам использования искусственного интеллекта «Artificial Intelligence Journey», на которой в ходе обсуждения темы «Искусственный интеллект - главная технология XXI века» было отмечено, что к 2025 г. в мире будет насчитываться более 40 млрд интеллектуальных устройств, из которых $90 \%$ будут обладать «умными функциями с элементами искусственного интеллекта» [14]. В этой связи справедливо задаться вопросами: сохранит ли право выработанный веками интеллектуальный потенциал и какова будет его доля в праве будущего? является ли право продуктом интеллектуальной сферы деятельности человека? Для того чтобы дать на них ответы, стоит в первую очередь проанализировать природу, понять сущность и содержание права в контексте интеллекта и интеллектуальной деятельности.

Вопрос определения сущности и содержания права является одним из основополагающих для всей теории права. Это выступает предметом изучения в философии права, что не упрощает, а, наоборот, в какойто степени усложняет решение многих задач, поскольку философия не дает однозначных ответов, а призывает к осмыслению и осознанию проблем. Вероятно, именно поэтому Цицерон называл философию наукой о мудрости («философия - это любовь к мудрости»).

Стоит отметить, что понятия «сущность» и «содержание» являются нетождественными. Категория «сущность» показывает, каковы природа явления, предназначение, черты и свойства. Сущность неизменна, поскольку в противном случае изменится и само явление. Сущность явления выражается в его функциях, то есть основных направлениях деятельности (или непосредственно деятельности). Категория «содержание» диалектически связана с категорией «форма», являясь для нее парной. Если форму можно определить как внешнее выражение чего-либо, какого-либо объекта или явления, то содержание - это «совокупность тех элементов или процессов, которые составляют основу объектов и обуславливают существование, развитие и смену форм» [34, c. 463].

На необходимость разграничения понятий «сущность права» и «содержание права» обращали внимание В. А. Толстик и Н. А. Трусов, отмечая, что отождествление данных понятий является методологической ошибкой, поскольку нарушение правил формальной логики ведет к удвоению понятийного аппарата. Сущность права данные ученые характеризуют как «главную внутреннюю, относительно устойчивую качественную основу права, которая отражает его истинную природу и назначение в обществе» [32, с. 6]. В свою очередь, содержание права представителями нижегородской школы права определяется как система исходящих от государства норм права. Разделяя в целом данную позицию, считаем необходимым далее рассмотреть именно сущность права, то есть его качественную основу и истинную природу. 
Сущность права в основных концепциях правопонимания

Обратимся к анализу понимания сущности права в политико-правовых учениях различных правовых школ. Представители естественно-правовой теории происхождения права рассматривают право с позиции идей равенства и свободы, справедливости, признания неотчуждаемости прав и свобод человека, существования прав, отражающих идеалы свободы и справедливости, которые выступают основой для права в его позитивном понимании. Так, Гуго Гроций, разделяя право на естественное и волеустановленное (в рамках которого также выделял человеческое и божественное), писал, что право «имеет своим источником волю». Источником права внутригосударственного выступает воля законодателя, а право божественное имеет источником божественную волю. Источник естественного права Г. Гроций видел в «здравом разуме, коим то или иное действие, в зависимости от его соответствия или противоречия самой разумной природе, признается либо морально позорным, либо морально необходимым» [7].

Томас Гоббс в своем труде «Левиафан, или Материя, форма и власть государства церковного и гражданского» писал, что «воля законодателя есть закон». В свою очередь, под естественным законом Т. Гоббс понимал «предписание, или найденное разумом (reason) (курсив наш - A. К.) общее правило, согласно которому человеку запрещается делать то, что пагубно для его жизни или что лишает его средств к ее сохранению» [4, c. 89].

Согласно концепции исторической школы права право каждого народа - это выражение общего сознания или общей воли данного народа, сложившееся исторически. Густав фон Гуго отмечал, что писаный закон возникает по воле суверена, но при этом подчеркивал, что «не все законоположения возникают из писаных законов» [21, с. 44]. Закон, по мнению Г. Гуго, это «правило, установленное произвольно верховной властью и что-либо запрещающее и предписывающее». Основатель исторической школы права, отмечая осознанность и признание правовых норм в качестве обязательного признака результативного действия права, писал, что «право, действующее в жизни и признаваемое судьями, адвокатами и учеными-юристами, может отличаться от права, установленного законодателем» [21, с. 46].
Продолжатель идей Г. Гуго Фридрих Карл фон Савиньи полагал, что сущность права состоит в том, что оно существует в общем сознании народа как народная убежденность, а господство индивидуальной воли называл сущностью правоотношений [29].

Психологическая школа права рассматривает сущность права с позиции правовых эмоций и эмоционально-интеллектуальных переживаний человека, которые в одном случае носят атрибутивный характер и связаны с правомочием человека на что-либо, а в другом - императивный характер и возникают вследствие осознания человеком взятых на себя обязанностей. В дореволюционной России фундаментально данная теория была разработана в трудах Л. И. Петражицкого. Ученый предложил классифицировать право на интуитивное и позитивное в зависимости от императивно-атрибутивных переживаний, формирующихся в психике человека в связи с юридическими фактами. При этом волевая сторона правообразования абсолютно не отрицалась: «в связи с договором, до его заключения, во время заключения или после, может также иметь место и подлинное выражение воли» [24, C. 454].

Несмотря на то что современные ученые рассматривают правовую парадигму Л. И. Петражицкого как социологически ориентированную, имеющую социальный эффект [31], а право в его представлении как социально-психически обусловленное явление [28, с. 121], роль интеллектуального начала (разума) в формировании и действии права неоднократно подчеркивалась русско-польским ученым. Во-первых, правовые нормы характеризовались Л. И. Петражицким как «особого рода фантазмы», то есть представления, возникающие в результате работы эмоционально-интеллектуальных процессов человеческого организма. Появлению эмоций по поводу управомочивания или обязывания предшествовал интеллектуальный процесс осознания («путем ассоциации идей или умозаключений»). Во-вторых, ученым делался акцент на необходимости трансформации в теории права учения о правовых явлениях в учение об эмоционально-интеллектуальных элементах правовых переживаний. В-третьих, отличие интуитивного и позитивного права в содержательном аспекте основатель отечественной психологической теории права видел в «различиях ин- 
теллектуального состава». Стоит заметить, что интуитивное право Л. И. Петражицкий не рассматривал как идеальное, а, наоборот, считал, что успешное существование и развитие общества на основе одного интуитивного права невозможно. В ряде случаев ученый называл его неразумным, варварским, более отсталым, чем позитивное право. В-четвертых, факт издания законов без интеллектуального осознания, по мнению Л. И. Петражицкого, не приводит к формированию права в психике человека. Таким образом, стоит заметить, что, несмотря на то что источником права, согласно психологической концепции, выступает психика человека, средством формирования права, то есть фактически инструментом осознания и выработки психологических эмоций по поводу права, является интеллект, или разум, человека.

Нормативистская школа права определяет сущность права исключительно как производную от воли независимо от каких-либо внешних факторов. Основоположник классического нормативизма Иммануил Кант природу права связывал с «категорическим императивом» - требованием общеобязательного характера. Подчеркивая значимость идей И. Канта для всей теоретико-правовой науки, профессор И. В. Михайловский заметил: «Кант первый дал философское обоснование самоцельности личности, ее нравственной автономии. Только с этого момента и можно говорить об идее права» [20].

Согласно учению И. Канта право по своей природе выступает сложным явлением, которое, с одной стороны, рассматривается как средство обеспечения свободы, а с другой - средство, сдерживающее свободу с целью недопущения негативных последствий проявления физиологических инстинктов, пороков, природы человека. В философских воззрениях И. Канта красной нитью проходит идея разума как исходного начала мира идей и мира вещей. Правопонимание также не лишено разумного начала: «право - это именно такое основанное на чистом практическом разуме понятие произвола, подчиненного законам свободы» [12, с. 5]. Как справедливо отмечает Л. С. Мамут, «разум, по Канту, есть способность (и воля) создавать принципы и правила морального поведения, содержащая их в себе в качестве внутреннего априорного побуждения» [10, с. 401]. Интеллектуальное познание многих явлений в контексте права И. Кант противо- поставлял эмоциональному, или чувственному: правовые отношения, к примеру, называл абсолютно интеллектуальными, подчеркивал, что владение должно осознаваться, то есть мыслиться как таковое, на основе интеллектуального отношения к предмету, а не на основе чувств, совершение юридически значимых действий (приобретение, владение, пользование) - основываться на воле заинтересованных субъектов, которая исходит от разума, заявлял, что рассматриваться в качестве правовых могут только «рассудочные понятия», и т. д.

Естественное право немецкий философ рассматривал исключительно как познаваемое разумом каждого человека, а государственное право - как нечто, что есть в разуме и основывается на априорных принципах. В целом, согласно И. Канту, «право вовсе не может являться, его понятие содержится в рассудке и представляет (моральное) свойство поступков, присущее им самим по себе» [11, с. 71].

Ганс Кельзен, пытаясь избежать «методологического синкретизма», старался отграничить юридическое понимание права от представления о нем в смежных науках психологии, философии, социологии. Свое учение о праве он назвал «чистым», поскольку оно «есть правоведение, но не политика права» [13, с. 10]. Согласно Г. Кельзену право - это система регулирующих человеческое поведение норм, которые по своему содержанию есть «долженствование». Понятие «долженствование» философ рассматривал гораздо шире, чем в значении простой обязанности: оно объединяло в себе такие элементы, как «должен», «может» и «имеет право». Долженствование, то есть то, что закреплено в нормах права (то, что должно быть), в учении Г. Кельзена противопоставляется бытию, то есть тому, что есть на самом деле. Способность определить степень соответствия бытия долженствованию возлагается на человеческое сознание. Именно в результате мыслительного процесса сопоставления событий из реального мира с нормами гражданского, уголовного, уголовно-процессуального кодекса или конституции они становятся правовыми. По мнению Г. Кельзена, «содержание долженствования - то, что велит позитивный моральный или правопорядок, - определяется актами воли, а уж затем познается» [13, с. 15]. Вместе с тем австрийский ученый подчеркивал, что норма права может быть 
результатом мыслительного процесса, а не только воли субъекта. В этом случае она не является позитивной нормой, поскольку не введена в действие, а выступает мыслительной предпосылкой.

Представителем неопозитивистского направления в понимании права, ставшим известным как создатель лингвистической теории права, является Герберт Харт. Английский философ в целом разделял кельзеновскую концепцию понимания права. По мнению К. Г. Прокофьева и Д. В. Шкрума, камнем преткновения теорий Г. Кельзена и Г. Харта был вопрос о природе «основной нормы»: учение Г. Кельзена обосновывало априорную природу, а Г. Харт настаивал на эмпирической природе нормативных фактов [25, с. 192]. Сущность права Г. Харт видел в единстве первичных (обязывающих) и вторичных (правил изменения, признания и суда) правил. Разработав формулу первичных и вторичных норм права, а также первичных и вторичных норм морали, Г. Харт проводит между ними границу: «утверждение, что право должно соответствовать морали в каком-то более далеко идущем отношении... нуждается в очень серьезной проверке» [35, с. 204]. Вместе с тем право и мораль в учении Г. Харта взаимосвязаны между собой требованием справедливости. Интеллектуальное начало в понимании права встречается и здесь: Г. Харт отмечал, что принципы истинной нравственности и справедливости способны познаваться только человеческим разумом, человеческий разум способен дать критическую оценку закону, обосновать его справедливость или несправедливость, сам разум «требует добровольного сотрудничества в системе принуждения» [35, с. 200].

Далее стоит несколько слов сказать о, пожалуй, самой влиятельной философской школе XX в. - марксистской теории права. «Представители» данного направления определяют право как возведенную в закон волю господствующего класса и рассматривают его как надстройку над экономическим базисом общества. Термин «представители» приводится в кавычках не случайно, ведь подобное понимание сущности права зачастую не отражало истинных идей материалистов, а представляло собой искаженную интерпретацию правоведами (особенно в политико-правовой доктрине советского периода) учения К. Маркса и Ф. Энгельса. И это вполне объяснимо. Критиковать поли- тико-правовые идеи марксизма-ленинизма в годы СССР было аполитично, если не сказать противоправно, поэтому восприятие и неправильное уяснение идей К. Маркса и Ф. Энгельса одними учеными эклектично излагалось в научных трудах других без проведения подробного, всестороннего и критического анализа. В итоге сущность и содержание многих понятий были искаженно поняты и еще более искаженно донесены до читателя.

Приведем несколько цитат советских ученых. Одним из первых определил право как «совокупность правил поведения (норм), установленных или санкционированных советским социалистическим государством, выражающих волю советского народа» [22, с. 183] А. Я. Вышинский в ходе І Совещания научных работников права в 1938 г. Предложенный подход к пониманию права стал в какой-то степени эталоном для всей теоретико-правовой науки и признавался многими ведущими теоретиками права. Так, О. С. Иоффе и М. Д. Шаргородский предложили рассматривать право, основываясь «на тех посылках, что и общее определение понятия права, данное в 1938 г.» [9, с. 59]; Н. Г. Александров назвал предложенную А. Я. Вышинским трактовку права «безусловно правильной» [1, с. 204]; определение права, предложенное Г. И. Федькиным, отмечалось учеными как «новая редакция определения Вышинского» [5, с. 19]. А. А. Гордиенко, несмотря на критику в адрес А. Я. Вышинского (в своей работе «Сущность советского права и его роль в социалистическом обществе» дефиницию, предложенную А. Я. Вышинским, ученый назвал навязанной и содержащей явные пороки), также рассматривал право как «возведенную в закон государственную волю рабочего класса и руководимых им трудящихся», а под его сущностью понимал «объективное содержание государственной воли» [5, с. 23].

Если обратиться к тексту знаменитого «Манифеста Коммунистической партии» К. Маркса и Ф. Энгельса, то, действительно, можно обнаружить, что право в нем определяется как «возведенная в закон воля вашего класса (курсив наш - А. К.), воля, содержание которой определяется материальными условиями жизни вашего класса» [36, с. 42]. Однако здесь знаменитые философы речь ведут о праве буржуазном, то есть о том праве, которое является эксплуататорским, праве в руках буржуа, праве, с которым 
нужно бороться. В. М. Сырых, называя материалистическую теорию права фальсифицированной советской правовой наукой по ряду вопросов, утверждает: «К. Маркс и Ф. Энгельс вопреки утверждениям советских авторов не говорили и не писали о том, что государственная воля экономически и политически господствующего класса составляет сущность права, а государственное принуждение - его главный отличительный признак» [30, с. 14]. И действительно, в «Критике политической экономии» в 1959 г. К. Маркс писал о правовых отношениях: «они коренятся в материальных жизненных отношениях, совокупность которых Гегель, по примеру английских и французских писателей XVIII века, называет "гражданским обществом"...» [18, с. 6]. Таким образом, материальные жизненные отношения, согласно учению К. Маркса, есть основа правовых отношений или самого права.

Данную позицию можно проследить в работах советского ученого А. И. Денисова. Ученики А. И. Денисова отмечают, что Андрей Иванович был приверженцем исторического и классового подхода. В. В. Лазарев, например, отзывался о нем как об исследователе, который «совершенно искренне пропагандировал (в части советского государства развивал) марксистскую теорию государства» $[15$, с. 108]. Несмотря на то что право, по мнению А. И. Денисова, это возведенная в закон воля господствующего класса, основой его он считал не волю (тем самым подвергая критике «буржуазных теоретиков»), а материальные условия жизни людей. Кроме того, профессор рассматривал право в объективном (как закон или совокупность законов) и субъективном смысле (как правомочие). Также в работах А. И. Денисова можно проследить идеи рационализма в вопросе понимания сущности права: «нельзя понять право, не касаясь вопроса о свободе воли, об отношении между свободой и необходимостью» [8, с. 299]. При этом воля, по убеждению ученого, представляла собой нечто осознанное: результат осознанных общественных отношений, осознанную необходимость или вид сознания.

Возвращаясь к идеям К. Маркса и Ф. Энгельса, стоит заметить, что не только экономические или волевые аспекты в понимании разных сторон устройства мира затрагивались в работах немецких философов. Обращение к разуму (интеллекту, в том числе всеобщему) как явлению, сопровождающе- му многие стороны общественной жизни, дает основание рассмотреть марксизм с позиций рационализма. Философия марксизма, оказавшая существенное влияние на переосмысление многих философских проблем, не могла обойти вниманием проблему соотношения рационального и иррационального. Американский историк Алан Мегилл в своем произведении «Карл Маркс: бремя разума» подчеркивал: «Замысел моего исследования заключается в доказательстве того, что Маркс должен быть понят как "рационалист"» [19, с. 15]. Несмотря на дискуссионность и нелогичность отдельных теоретических умозаключений в работе А. Мегилла, искренность и стремление доказать выдвинутую гипотезу заслуживают уважения.

Относительно понимания государства и права можно заметить, что в работах немецких философов мы довольно часто встречаем отзвуки рационализма, выраженные в таких конструктах, как государственный разум, разум и право, разумная воля, разумный закон, нравственный разум. В одной из первых своих публицистических статей «Заметки о новейшей прусской цензурной инструкции», вышедшей в свет в 1842 г., К. Маркс отметил, что «рассудок правительства - единственный государственный разум» [16, с. 8]. В статье «Передовица в № 179 "K Inische Zeitung"» он писал: «истинная "общественно-воспитательная роль" государства заключается в его разумном и общественном бытии» [17, с. 103]. Рационализм в понимании права в идеях К. Маркса можно выразить следующими тезисами.

Во-первых, государство и право - это неотъемлемые элементы построения и функционирования общественной жизни. При этом в основе возникновения и становления как государства, так и права лежат разум и социум. Развивая данную идею, Н. А. Власенко справедливо задается вопросом о степени разумности современного государства и роли, выполняемой социумом, в качестве основополагающего элемента государственности [2, с. 10].

Во-вторых, развитие права и государства детерминировано материальными экономическими отношениями общества. Право, как и государство, в данном случае выступает способом или средством, обеспечивающим сохранение, развитие и преумножение существующих связей между людьми, в результате чего члены общества в конечном итоге 
приобретают для себя нечто ценное, необходимое, осознаваемое как жизненно важное.

В-третьих, материальные экономические отношения, составляющие обычное право, могут приобрести форму закона и статус государственных только в том случае, если не противоречат разуму и праву. Противоречивость или непротиворечивость в данном случае определяется как результат осознанности или неосознанности определяемых целей, поставленных задач, осуществляемых действий. Государство, согласно идеям марксизма, «действует и поступает поэтому согласно осознанным целям, познанным основоположениям и согласно законам, которые являются законами не только в себе, но и для сознания».

Да и в целом стоит заметить, что революционные, антибуржуазные идеи, которые заложены в трудах К. Маркса и Ф. Энгельса, имели своей целью исключительно достижение необходимого уровня «интеллектуального развития рабочего класса».

В представленном исследовании нельзя обойти вниманием современные концепции правопонимания, в числе которых особый интерес представляет интегративный тип правопонимания профессора Р. А. Ромашова, который предлагает рассматривать право как регулятивно-охранительную систему, наделяя его двумя основными признаками: общезначимостью и результативностью. Согласно данной концепции право складывается из общезначимых норм (правил) для обеспечения безопасности, социальной стабильности и развития [26]. Помимо указанных ученым составляющих права (правовая доктрина, правовые ценности, правовой опыт, правовая традиция, правовая доктрина) представляется оправданным выделить правовые убеждения и правовые установки, которые, если и не составляют право, то оказывают важное влияние на процесс его формирования.

Серьезный научный интерес вызывает антропологическая концепция правопонимания, разработанная В. И. Павловым. Обусловлено это совершенно нестандартным, на наш взгляд, но методологически обоснованным подходом к пониманию права, его сущности и бытия, а также места и роли человека в системе права в рамках концепта «человек-в-праве». Прежде всего обращает на себя внимание тот факт, что белорусским ученым отрицаются классические концепции понимания сущностной природы права, вы- ражающейся в нормах, законах, воле законодателя или справедливости. Ученый пишет, что у права нет и не может быть какой-либо субстанциональной основы, то есть сущности как истинного бытия. Право, по В. И. Павлову, и есть сущность (существование).

С точки зрения антропологического подхода право осуществляется не в норме, а в «реальном, ежедневном опыте правового существования, в точке пересечения человека, нормы права и факта правовой жизни» [23, с. 85]. Кроме того, антропологическая концепция В. И. Павлова рассматривает человека в несколько необычном ключе - с позиции «принципа энергийности», то есть как некую совокупность проявлений или энергий (а не как сущность в классической антропологии). Через проведение параллели с пониманием человека в православной традиции человек или человеческое существование определяется как энергийный образ (центр энергии). При этом мы видим, что В. И. Павлов, разделяя позицию Х. Яннараса, С. А. Чурсанова, В. Н. Лосского, подчеркивает невозможность сведения человеческой личности даже к таким ее сторонам, как человеческая природа, разум, свободная воля, ум.

Несмотря на концептуальную разработанность предложенной теории, возникает ряд вопросов, требующих определенного научного осмысления. Во-первых, если рассматривать человека как некий «энергийный образ», требуются пояснения относительно природы или источника данной энергии, учитывая отказ автора от рассмотрения разума, свободной воли или ума в качестве таковых, ведь первый закон сохранения энергии гласит о том, что энергия не может взяться из ниоткуда и исчезнуть в никуда. По нашему мнению, в качестве производителя этой энергии могут выступать отмеченные стороны человеческой личности: разум, свободная воля или ум. Стоит заметить, что в некоторых приведенных трактовках понятия «энергия» сам В. И. Павлов предлагает определять данное явление следующим образом: «вечно движущая сила разумной (курсив наш - A. К.) души человека» [23, с. 75]. Во-вторых, восприняв предложенные формулы «право есть существование» и «человек-в-праве», справедливо задаться вопросом об их применимости К иным явлениям социума или природного мира. Можно ли по аналогии провести анализ возникновения и существования иных 
социальных регуляторов: традиций, обычаев, религиозных норм? Допускается ли применение формулы «право - это и есть существование» для традиций или обычая? На наш взгляд, эти вопросы остаются открытыми. В-третьих, антропологический тип правопонимания акцентирует внимание на становлении права, которое предлагается рассматривать как «правовое существование человека-в-праве». При этом все-таки, на наш взгляд, понимание причин возникновения и развития права у одних народов и его отсутствия вплоть до настоящего времени у других (например, у племен, проживающих на территории современного Пакистана или Камбоджи) в рамках антропологической концепции не достигнуто. И непонятно, может ли антропологическая концепция объяснить причины столь длительного отсутствия правовых норм в древности.

\section{Интеллектуальная природа права}

Представления различных научных школ о сущности и природе права, безусловно, разнятся. При этом мы убедились, что в каждой концепции правопонимания интеллект (ум, разум, рассудок) признается неотъемлемым элементом процесса правообразования. С учетом изложенного предлагаем рассмотреть право в рамках антропологического подхода как результат интеллектуальной деятельности человека не только по своему происхождению, но и сущностному основанию, своей природе.

Выдвижение тезиса об интеллектуальной природе права обусловлено следующими причинами. Во-первых, результатом исторического прогресса является накопление все большего и качественно нового знания, являющегося итогом интеллектуальной деятельности человека и выступающего мощнейшим ресурсом в процессе развития общества и управления им. Право - продукт рационального мышления - представляет собой особую ценность, свидетельствующую об уровне развития общества. На протяжении всей истории право вбирало в себя фундаментальные ценности и моральнонравственные установки, которыми данное общество обладает, и с формально-юридической точки зрения получало закрепление в нормах законодательства. Как справедливо отмечено Н. А. Гредескулом, право - это мудрец, который «неустанно работает, стремясь достигать того добра, которое практически возможно в данном общежитии, который никогда не приходит в отчаяние, потому что ценит те результаты, каких ему удается достигнуть своими усилиями» [6, с. 54].

Во-вторых, право адресовано человеку и только человеку. Несмотря на то, что встречаются случаи, когда субъектом права могут выступать неодушевленные предметы или животные (например, правосубъектность животных можно усмотреть в законодательстве стран англосаксонской правовой семьи), это является, скорее, исключением из правил, поскольку право в конечном счете свое действие оказывает на человека, в том числе в указанных случаях, поскольку человек здесь выступает в роли связующего звена. Только человек, в отличие от остальных представителей животного мира, обладает в необходимой степени развитыми интеллектуальными способностями.

В-третьих, интеллектуальная природа права подтверждается его постоянным развитием. Зарождение правовых норм, их трансформация, обретение свойств системности и структурности, формирование системы права в ее современном понимании, специализация и отраслевая дифференциация правовых норм, появление и дифференциация предметов и методов правового регулирования, законодательное закрепление правовых норм, развитие технико-юридических способов и средств формулирования и закрепления правовых норм - все это свидетельствует о постоянном качественном интеллектуально обоснованном развитии права. Стоит добавить, что современный человек находится в выигрышном положении, поскольку ему достаются в наследство все достижения в области права, полученные за тысячелетнюю историю. Следует привести слова А. Рэнд, которая в одном из своих произведений отметила, что «человек - единственный вид, который может расширять и передавать свой багаж знаний из поколения в поколение; объем знаний, потенциально доступных человеку, больше, чем любой человек на протяжении одной своей жизни способен хотя бы начать постигать» [27, с. 55].

Далее следует обосновать избранное для подзаголовка сочетание «интеллектуальная природа права». С этой целью необходимо обратиться к вопросу о соотношении понятий «интеллект», «рассудок», «разум». Все они характеризуют разновидности умственной деятельности, заключающейся в познании явлений или предметов окружающего мира, или мышления. Толковые словари раскрыва- 
ют значение слова «интеллект» как «способность мышления, разумного познания, ум, разум, рассудок». Философская энциклопедия рассматривает понятие «интеллект» (от лат. intellectus - познание, понимание, рассудок) как тождественное понятию «ум» в следующем значении: «способность мышления, рационального познания, в отличие от таких душевных способностей, как чувство, воля, интуиция, воображение» [33]. Исследование научной литературы относительно методологических аспектов соотношения интеллекта, разума и рассудка позволяет заключить, что рассудок - это начальное звено в мыслительном процессе, он трансформирует мысли, идеи и образы с помощью языковой формы в идентифицируемую модель. Интеллект выступает развитой формой рассудка, которая сочетает в себе как индуктивное, так и дедуктивное мышление (рассудок ограничивается только индуктивным методом мышления). Интеллектуальное мышление отличается более высокой скоростью проведения мыслительных операций, а также использует такие нерациональные формы мышления, как интуиция, предвидение, воображение. Что касается разума или разумного мышления, то его стоит определить как высшую мыслительную способность человека. Разум, в отличие от рассудка, как писал И. Кант, «сохраняет за собой одну лишь абсолютную целокупность в применении рассудочных понятий и стремится довести синтетическое единство, которое мыслится в категориях, до абсолютно безусловного» [11].

Отдавая должное философам и правоведам прошлого, стоит признать, что исследование разумного мышления в контексте понимания природы и сущности права как высшего проявления мыслительных способностей человеческого организма было не случайным. В этом видится желание абсолютизировать право и придать ему безусловный характер как величайшему достижению человеческого (именно человеческого!) прогресса. Однако если бы право было продуктом исключительно мирового разума (логос, нус, слово божье) без участия интеллектуального мышления человека, то вряд ли было столь явным, к примеру, отставание правового регулирования от технологического прогресса (по мнению некоторых ученых, речь идет о десятилетнем разрыве). Другой пример связан с бесконечным массивом дополнений и поправок, вносимых в действующее законодательство, свидетельствующих о низком качестве законов, спешности их принятия, отсутствии концептуальности в планировании и прогнозировании результатов правового регулирования. Причина всего этого, по мнению Н. А. Власенко, кроется в самом разуме, который может пренебрегать закономерностями права, манипулировать правовыми механизмами или попросту «не уважать его» [3, с. 12]. Да и в целом стоит сказать, что разум не является абсолютной величиной, он небезупречен и зачастую ограничен объективными и субъективными факторами.

\section{Выводы}

Разумное мышление - это уникальное явление, способность и одновременно принцип жизни человека. Только человек как разумное существо способен изменять окружающую его реальность, противостоять пагубному влиянию природы, в отличие от животных, которые приспосабливаются к среде обитания. Право в данном аспекте непосредственно связано с разумом. Разум одновременно выступает а) сущностью права, его источником; б) принципом (принцип разумности), лежащим в основе системы построения, развития (совершенствования) и функционирования правовых механизмов; в) средством, лежащим в основе правопонимания и интерпретации права, выраженного в правовых нормах.

Таким образом, на основе проведенного анализа автором предлагается следующее определение права: это результат интеллектуально-разумной мыслительной деятельности человека, выраженный в информационном комплексе правил поведения, синергийно организованных в упорядоченную систему. В соответствии с данной дефиницией признаками права стоит считать системность и интеллектуальную производность. Под системностью следует понимать упорядоченную в систему, объединенную наличием внутренних и внешних связей совокупность норм (правил поведения). Внутренняя системность предполагает наличие у системы права свойств целостности, саморегуляции, непрерывности и интеграции. Внешняя системность задает взаимодействие системы права с другими регуляторами общественного поведения. Признак интеллектуальной производности состоит в том, что право является результатом интеллектуально-разумной мыслительной деятельности человека. 


\section{СПИСОК ЛИТЕРАТУРЫ}

1. Александров, Н. Г. Право и законность в период развернутого строительства коммунизма / Н. Г. Александров. Москва : Госюриздат, 1961. - 271 с.

2. Власенко, Н. А. Методологические проблемы современной теории права / Н. А. Власенко // Журнал российского права. - 2019. - № 4 (268). - С. 5-19.

3. Власенко, Н. А. Разумность и определенность в правовом регулировании / Н. А. Власенко. - Москва : Институт законодательства и сравнительного правоведения при Правительстве Российской Федерации : ИНФРА-М, 2014. 157 с. - ISBN 978-5-16-010271-9.

4. Гоббс, Т. Левиафан, или материя, форма и власть государства церковного и гражданского / Томас Гоббс // Lib. Ru: Библиотека Максима Мошкова. - URL: http://lib.ru/FILOSOF/GOBBS/leviafan.txt (дата обращения: 15.02.2021).

5. Гордиенко, А. А. Сущность советского права и его роль в социалистическом обществе / А. А. Гордиенко. - Ташкент : Фан, 1967. - 147 с.

6. Гредескул, Н. А. К учению об осуществлении права. Интеллектуальный процесс, требующий для осуществления права / Н. А. Гредескул. - Харьков : Тип. А. Дарре, 1900. - 235 с.

7. Гроций, Г. О праве войны и мира. Книга первая / Г. Гроций // Гражданское общество в России : научная электронная библиотека. - URL: https://www.civisbook.ru/files/File/Groziy Kn1.pdf (дата обращения: 15.02.2021).

8. Денисов, А. И. Теория государства и права / А. И. Денисов. - Москва : Юридическое издательство Министерства юстиции СССР, 1948. - 532 с.

9. Иоффе, О. С. Вопросы теории права / О. С. Иоффе, М. Д. Шаргородский. - Москва : Госюриздат, 1962. - 381 с.

10. История политических и правовых учений : учебник для вузов / под общей редакцией В. С. Нерсесянца. - Изд. 2-е, стереотип. - Москва : Издательская группа НОРМА-ИНФРА-М, 2000. - 736 с. - ISBN 5-89123-442-4, ISBN 5-16000322-3

11. Кант, И. Критика чистого разума / Иммануил Кант. - URL: https://librebook.me/critique_of_pure reason (дата обращения: 04.03.2021).

12. Кант, И. Метафизика нравов. Учения о праве. Часть первая / И. Кант // Гражданское общество в России : научная электронная библиотека. - URL: https://www.civisbook.ru/files/File/Kant_Metaphisika_2.pdf (дата обращения: 04.03.2021).

13. Кельзен, Г. Чистое учение о праве / Ганс Кельзен. - Санкт-Петербург : Алеф-Пресс, 2015. - 542 c. - ISBN $978-5-$ 905966-54-5.

14. Конференция по искусственному интеллекту // Президент России : официальный caйт. - URL: http://www. kremlin.ru/events/president/news/64545 (дата обращения: 15.02.2021).

15. Кроткова, Н. В. Общая теория права: история и современное состояние. К 110 -летию со дня рождения А. И. Денисова (1906-1984) / Н. В. Кроткова // Государство и право. - 2017. - № 4. - С. $107-125$.

16. Маркс, К. Заметки о новейшей прусской цензурной инструкции / K. Маркс // Marxists Internet Archive. - URL: https://www.marxists.org/russkij/marx/cw/t01.pdf (дата обращения: 04.03.2021).

17. Маркс, К. Передовица в № 179 «K Inische Zeitung» / K. Mapкc // Marxists Internet Archive. - URL: https://www. marxists.org/russkij/marx/cw/t01.pdf (дата обращения: 04.03.2021).

18. Маркс, К. Сочинения. Том XII. Часть 1 / К. Маркс, Ф. Энгельс ; под ред. В. Адоратского. - Москва : Партиздат ЦК ВКП(б), 1935. - 603 с.

19. Мегилл, А. Карл Маркс: бремя разума / Алан Мегилл. - Москва : Канон +, 2011. - 335 с. - ISBN 978-5-88373254-2.

20. Михайловский, И. В. Очерки философии права. Том 1 / И. В. Михайловский. - Томск : В. М. Посохин, 1914. $632 \mathrm{c}$.

21. Немецкая историческая школа права. - Челябинск : Социум, 2010. - 528 с. - ISBN 978-5-91603-033-4.

22. Основные задачи науки советского социалистического права : доклад А. Я. Вышинского, прения и заключительное слово на І совещании по вопросам науки советского государства и права (16-19 июля 1938 г.). - Москва : Юриздат, 1938. - 192 с

23. Павлов, В. И. К вопросу об антропологическом типе правопонимания / В. И. Павлов // Правоведение. - 2015. № 4 (321). - С. 71-97.

24. Петражицкий, Л. И. Теория права и государства в связи с теорией нравственности. Том 2 / Проф. Л. И. Петражицкий. - Санкт-Петербург : Тип. М. Меркушева, 1910. - 758 с.

25. Прокофьев, К. Г. Г. Кельзен и Г. Харт о нормативной природе средств правового и морального регулирования социальных процессов / К. Г. Прокофьев, Д. В. Шкрум // Юридическая наука: история и современность. - 2019. № 9. - C. 188-195.

26. Ромашов, Р. А. Реалистический позитивизм: интегративный тип современного правопонимания / Р. А. Ромашов // Известия высших учебных заведений. Правоведение. - 2005. - № 1 (258). - С. 4-11.

27. Рэнд, А. Добродетель эгоизма / Айн Рэнд. - Москва : Альпина Паблишер, 2018. - 267 с. - ISBN 978-5-96147069-7.

28. Савенков, А. Н. Л. И. Петражицкий как социолог права / А. Н. Савенков, В. С. Горбань // Социологические исследования. - 2019. - № 3. - С. 118-128.

29. Савиньи, Ф. К. фон. Система современного римского права. В 8 томах. Том 1 / Фридрих Карл фон Савиньи ; под редакцией О. Кутателадзе и В. Зубаря. - Москва : Статут, 2011. - 510 с. - ISBN 978-5-8354-0769-9.

30. Сырых, В. М. Материалистическая теория права : избранное / В. М. Сырых. - Москва : Рос. акад. правосудия, 2011. - 1259 с. - ISBN 978-5-93916-302-6.

31. Тимошина, Е. В. Теория и социология права Л. И. Петражицкого в контексте классического и постклассического правопонимания : диссертация на соискание ученой степени доктора юридических наук / Тимошина Елена Владимировна. - Москва, 2013. - 556 с.

32. Толстик, В. А. Понятие содержания права / В. А. Толстик, Н. А. Трусов // Государство и право. - 2014. - № 6. C. $5-13$.

33. Философская энциклопедия. - URL: https://dic.academic.ru/dic.nsf/enc_philosophy/2361 (дата обращения: 20.03.2021).

34. Философский словарь / под редакцией М. М. Розенталя и П. Ф. Юдина. - Москва : Политиздат, 1963. - 544 с. 
35. Харт, Г. Л. А. Понятие права / Г. Л. А. Харт ; под общей редакцией Е. В. Афонасина, С. В. Моисеева. - СанктПетербург : Изд-во Санкт-Петербургского ун-та, 2007. - 302 с. - ISBN 978-5-288-04211-9.

36. Энгельс, Ф. Манифест Коммунистической партии / Фридрих Энгельс, Карл Генрих Маркс // Социалистическая Альтернатива : сайт. - URL: https://socialist.news/pic/truestory/marx-permanent-revolution/communist-manifesto.pdf (дата обращения: 04.03.2021).

\section{REFERENCES}

1. Aleksandrov N.G. Pravo i zakonnost'v period razvernutogo stroitel'stva kommunizma [Law and legality during the period of extensive construction of communism]. Moscow: Gosyurizdat, 1961. 271 p.

2. Vlasenko N.A. Methodological problems of the modern theory of law. Zhurnal rossiiskogo prava=Journal of Russian Law, 2019, vol. 268, no. 4, pp. 5-19. (In Russ.).

3. Vlasenko N.A. Razumnost' i opredelennost' v pravovom regulirovanii [Reasonableness and certainty in legal regulation]. Moscow: Institut zakonodatel'stva i sravnitel'nogo pravovedeniya pri Pravitel'stve Rossiiskoi Federatsii: INFRA-M, 2014. $157 \mathrm{p}$.

4. Gobbs T. Leviafan, ili materiya, forma i vlast' gosudarstva tserkovnogo i grazhdanskogo [Leviathan or the matter, forme and power of a commonwealth ecclesiasticall and civil]. P. 89. Available at: http://lib.ru/FILOSOF/GOBBS/leviafan.txt (accessed February 15, 2021)

5. Gordienko A.A. Sushchnost' sovetskogo prava i ego rol' v sotsialisticheskom obshchestve [Essence of Soviet law and its role in socialist society]. Tashkent: Fan, 1967. $147 \mathrm{p}$.

6. Gredeskul N.A. K ucheniyu ob osushchestvlenii prava. Intellektual'nyi protsess, trebuyushchii dlya osushchestvleniya prava [To the doctrine of the exercise of law. Intellectual process that requires the exercise of law]. Kharkov: tip. A. Darre, 1900. 235 p.

7. Grotius G. O prave voiny i mira. Kniga pervaya. [On the law of war and peace]. Available at: https://www.civisbook.ru/ files/File/Groziy_Kn1.pdf (accessed February 15, 2021)

8. Denisov A.I. Teoriya gosudarstva i prava [Theory of the state and law]. Moscow: Yuridicheskoe izdatel'stvo Ministerstva yustitsii SSSR, 1948. $532 \mathrm{p}$.

9. Ioffe O.S., Shargorodskii M.D. Voprosy teorii prava [Law theory issues]. Moscow: Gosyurizdat, 1962. 381 p.

10. Istoriya politicheskikh i pravovykh uchenii: uchebnik dlya vuzov [History of political and legal doctrines: textbook for universities]. Ed by V.S. Nersesyants. Moscow: Izdatel'skaya gruppa NORMA-INFRA-M, 2000. 736 p.

11. Kant I. Kritika chistogo razuma [Critique of pure reason]. Available at: https://ebooks-free.net/kniga/kritika-chistogorazuma.html (accessed March 4, 2021).

12. Kant I. Groundwork of the metaphysics of morals. Part 1. Grazhdanskoe obshchestvo v Rossii : nauchnaya elektronnaya biblioteka [Civil Society in Russia : Scientific Electronic Library]. Available at: https://www.civisbook.ru/files/File/Kant_ Metaphisika_2.pdf (accessed March 4, 2021).

13. Kelzen G. Chistoe uchenie o prave [Pure theory of law]. Saint-Petersburg: OOO Izdatel'skii Dom "Alef-Press", 2015. $542 \mathrm{p}$.

14. Conference on Artificial Intelligence. Ofitsial'nyi sait Prezidenta Rossii. [Official web-site of Russian President]. Available at: http://www.kremlin.ru/events/president/news/64545 (accessed February 15, 2021).

15. Krotkova N.V. General theory of law: history and current state. the 110th anniversary of the birth of A. I. Denisov (19061984). Gosudarstvo i pravo=State and Law, 2017, no. 4, pp. 107-125. (In Russ.).

16. Marx K. Comments on the latest Prussian Censorship Instruction. Marxists Internet Archive. Available at: https://www. marxists.org/russkij/marx/cw/t01.pdf (accessed March 4, 2021).

17. Marx K. The Leading article in No. 179 of the K Inische Zeitung". Marxists Internet Archive. Available at: https://www. marxists.org/russkij/marx/cw/t01.pdf (accessed March 4, 2021).

18. Marx K., Engels F. Sochineniya. T. XII. Ch. 1. [Essays]. Vol.12. Part 1. Ed. by V. Adoratskii. Moscow: Partizdat TsK VKP(b), 1935. $603 \mathrm{p}$.

19. Megill A. Karl Marks: bremya razuma [Karl Marx: the burden of reason]. Translated from English. Moscow: Kanon +, 2011. 335 p.

20. Mikhailovskii I.V. Ocherki filosofii prava. T. 1 [Essays on the Philosophy of Law. Vol. 1]. Tomsk, 1914. 632 p.

21. Nemetskaya istoricheskaya shkola prava [German historical school of law]. Chelyabinsk, 2010. 528 p.

22. Osnovnye zadachi nauki sovetskogo sotsialisticheskogo prava : doklad A. Ya. Vyshinskogo, preniya i zaklyuchitel'noe slovo na I soveshchanii po voprosam nauki sovetskogo gosudarstva i prava (16-19 iyulya 1938 g.) [Key tasks of the science of Soviet socialist law: A.Ya. Vyshinsky's report, debates and closing remarks at the First meeting on the science of the Soviet state and law (July 16-19, 1938)]. Moscow : Yurizdat, 1938. 192 p.

23. Pavlov V.I. On the question of the anthropological type of understanding law. Pravovedenie=Understanding Law, 2015, vol. 321, no. 4, pp. 71-97. (In Russ.).

24. Petrazhitskii L.I. Teoriya prava i gosudarstva $v$ svyazi s teoriei nravstvennosti [Theory of law and the state in connection with the theory of morality]. Vol. 2Saint-Petersburg, 1910. $758 \mathrm{p}$.

25. Prokof'ev K.G., Shkrum D.V. G. Kelsen and G. Hart on the regulatory nature of the means of legal and moral regulation of social processes. Yuridicheskaya nauka: istoriya i sovremennost'=Legal Science: History and the Presence, 2019, no. 9, pp. 188-195. (In Russ.).

26. Romashov R.A. Realistic positivism: integrative type of modern understanding of law. Izvestiya vysshikh uchebnykh zavedenii. Pravovedenie= Proceedings of Higher Educational Institutions. Pravovedenie, 2005, vol. 258, no. 1, pp. 4-11. (In Russ.).

30. Rusakov V.M., Rusakova O.F. Problem and categories of rational and irrational in Classical Marxism. Diskursologiya: metodologiya, teoriya, praktika= Discoursology: methodology, theory, practice, 2018, no. 11, pp. 190-222. (In Russ.). 27. Rand A. Dobrodetel' egoizma [The Virtue of Selfishness]. Moscow: Al'pina Pablisher, 2018. 267 p.

28. Savenkov A.N., Gorban' V.S. L.I. Petrazhitsky as a sociologist of law. Sotsiologicheskie issledovaniya=Sociological Studies, 2019, no. 3, pp. 118-128. (In Russ.).

29. Savigny F.C. Sistema sovremennogo rimskogo prava [System of the Modern Roman Law]. Vol. 1. Translated from German by G. Zhigulin. Edited by O. Kutateladze, V. Zubary. Moscow: Statut, 2011. 510 p. 
30. Syrykh V.M. Materialisticheskaya teoriya prava: Izbrannoe [Materialistic theory of law: selected] Moscow: RAP, 2011. $1259 \mathrm{p}$.

31. Timoshina E.V. Teoriya i sotsiologiya prava L.I. Petrazhitskogo v kontekste klassicheskogo i postklassicheskogopravoponimaniya: diss. ... d-ra yurid. nauk [Theory and Sociology of Law by L. I. Petrazhitskii in the context of classical and postclassical understanding of law: of Doctor of Sciences (Law) dissertation]. Moscow, 2013. 556 p.

32. Tolstik V.A., Trusov N.A. The notion of the content of law. Gosudarstvo i pravo=State and Law, 2014, no. 6, pp. 5-13. (In Russ.).

33. Filosofskaya entsiklopediya [Philosophical encyclopedia]. Available at: https://dic.academic.ru/dic.nsf/enc_philosophy/2361 (accessed March 20, 2021)

34. Filosofskii slovar' [Philosophical dictionary]. Ed. by M.M. Rozental' and P.F. Yudin. M., 1963. 544 s.

35. Hart H. L. A. Ponyatie prava [The Concept of law]. Ed. by E.V. Afonasin and S.V. Moiseev. Saint-Petersburg: Izd-vo S.Peterb. un-ta, 2007. 302 p.

36. Engels F., Marx K. Manifesto of the Communist Party. Sotsialisticheskaya Al'ternativa: sait [Sociological alternative: website]. Available at: https://socialist.news/pic/truestory/marx-permanent-revolution/communist-manifesto.pdf (accessed March 4, 2021).

\section{CВЕДЕНИЯ ОБ АВTOPE / INFORMATION ABOUT THE AUTHOR}

АЛЕКСЕЙ АЛЕКСЕЕВИЧ КОСЫХ - КандИДат юрИдИческих наук, доцент, доцент кафедры государственноправовых дисциплин Академии управления МВД России, г. Москва, Российская Федерация, ORCID: https:// orcid.org/0000-0002-3563-6848, e-mail: lexovip36@mail. ru
ALEKSEI A. KOSYKH - Candidate of Sciences (Law), Associate Professor, Associate Professor of the Department for State and Legal Disciplines of the Academy of Management of the Ministry of Internal Affairs of the Russian Federation, Moscow, Russian Federation, ORCID: https:// orcid.org/0000-0002-3563-6848, e-mail: lexovip36@ mail.ru 